\title{
Mobile Learning Business Model Framework
}

\author{
${ }^{1}$ Alireza Nasiri*, ${ }^{2}$ Deng Gui Shi \\ ${ }^{1}$ Dongbei University of Finance and Economics, China \\ ${ }^{2}$ Dalian University of Technology, China \\ *a.nasiri@dufe.edu.cn
}

\begin{abstract}
M-learning has become more and more important but still is a young educational and economical (Edu-Eco) technology. M-learning strategies are aimed at economic, academic and technological objectives, however they lack in modeling ensured economic measurements in the sense of profitable products. Throughout this paper, we discuss the prime categories of elements that participate in the m-learning value net and give an overview of their business models. In addition to considering the mobile and e-learning business, business models, we deconstruct the m-learning value net, and also use a literature review in order to identify different actors in a business model for M-learning.
\end{abstract}

Keywords: M-learning, business model, business player, business environment, business framework

\section{Introduction}

Many M-learning providers offer unique products to achieve profits. Likely, they will become major players in the M-learning field. Others, who develop in the same way, or even with extra effort, may not succeed in supplying the field. A possibility for the cause of this phenomenon is their underlying business model. Unique and potent m-learning products face competition from older m-learning products. In contrast, some commercial suppliers of m-learning products are successfully offering their products; many have already developed pilot schemes for in-house training program, as well as a wide variety of research projects which their products are subjected to. A suitable and sustainable business model is vital in order to place m-learning products within commercial and practical levels. Unexpectedly, very little attention and capital has been allocated to research business models, a majority of the published works focus exclusively on Internet-based models. Available research is in a descriptive style, tending to examine approaches to creating models, defining regular business model styles, and referencing a long list of failed and successful models, they all share the idea that new business models are needed as conditions change. Business models are a comprehensive part of the m-learning strategy (Hoppe \& Breitner, 2003). The m-learning provider needs to consider an educational and a technical dimension to the task, as well as a strategic economic approach, therefore a business model is important to m-learning providers (Issack, Hosany \& Gianeshwar, 2006). Long term success for an m-learning provider can only be ensured by an integrated business model or business strategy. However, no agreement in regards of a definition for a model has been reached, there has not yet been an attempt to create an agenda for critical research and establishing research streams aimed at related questions. The research purpose of this study is to analyze and examine the existing points of view and frameworks for creating successful m-learning business models.

\section{Literature Review}

Definition of a 'Business model: 'Business Model' is possibly the most widely conversed term and also the least understood (Timmers, 1998) term in digital commercialism and mobile commercialism as well. In the past years, business model fields have developed from describing already existing mode through exploration and research into developing comprehensive business solutions. Firstly it is of a significant amount of importance to state what exactly a business model is. There has been no globally recognized meaning for 'business model' as a defined term. This varied and unstated definition creates a substantial amount of challenges for setting limits as to the nature and components of a model and creating a resolve on what creates a good model. This creates confusion in our terminology, as business model, strategy, business concept, revenue model and economic model are leisurely used in an interchangeable manner. The way a company or 
association of companies create consumer value and make their revenue is called a business model (Haaker, Bouwman \& Faber, 2004). A majority of business models which relate to e-businesses focus on the creation of value in association with their bricks and mortar counterparts (Alt \& Zimmermann 2001, Rappa 2001, Pigneur, 2002). In the highly turbulent and strictly competitive business environment the terminology creates 3 different but organized methods in dealing with the complex facts based on their business core: capacity for the creation of value, systems of operations, and thinking patterns within the company. While being very general, these three elements are conveyable in more solid and firm terms. As an example, capacity for the creation of value is a very resource oriented perception, whilst 'systems of operations' points at internal processes and value chains. In general, characteristic embodied by a company prove to be relevant in a certain strategic approach. Accordingly these types of perspectives can be divided as strategic, economic, and operational. These divides stand for a hierarchical perspective which becomes more and more comprehensive as we move through from economical to the operational to strategic levels within these categories.

At the foundation levels, a business model is defined exclusively out of the elements of the business' economic model. It deals with the method of generation of profit and maintaining the business. These elements range from revenue sources, pricing methods, structure of cost, margins, and volume expectation. From this, Stewart and Zhao (2000) define the model as "a statement of how a firm will make money and sustain its profit stream over time." The model symbolizes an architectural design which defines the business's operational intent. It focuses on the intra-company interactions and infrastructure which give the firm its financial and operational value. Some business components inside the model are the firm's production or methods of service delivery, resource flows, management of knowledge, administrative practices, and logistical streams. Mayo and Brown (1999) reference "the design of key interdependent systems that create and sustain a competitive business." Strategically defined models aim generally at the firm's position inside the market, its inter-organizational interactions, and growth prospects. Advantage in competition and sustainability are of most concern here. Elements aimed at the pure business side include identification of a firm's stakeholders, creation of value, differing from others, business networking and alliances, and lastly vision and values. Slywotsky (1996) references "the totality of how a company selects its customers, defines and differentiates its offerings, defines the tasks it will perform itself and those it will outsource, configures its resources, goes to market, creates utility for customers and captures profits."In a quick comparison of the available definitions, the strategic approach seems most outstanding. It is possible to also put the various other approaches into methods that are orderly and controlled. A 30 definition-wide content analysis of keywords brought authors to identify 3 general categories of approach. The first method is the review of the category of single business models. The second method is in relations with business model taxonomies.

Timmers created his taxonomy of nine business models in the field of electronic commerce with reference to degrees of originality and function integration (Timmers, 1998). Vashney and Vetter classified seven commercial mobile business models in the fields of mobile commercialism (Varshney \& Vetter, 2002). The third kind of approach is a consideration of generic business models as a framework which include various partial and fractal models (Pousttchi, Schießler \& Wiedemann, 2007). However, classifications in this field tend to be pointed on new opportunities created by the World Wide Web (Afuah \& Tucci, 2001) plus wireless mobile alternatives. Clearly technology is an important catalyst for pushing and deriving business models. Several few elements are there at the basic levels of a business model. Numerous researchers [(Afuah \& Tucci, 2001), (Bouwman, Haaker \& De Vos, 2008), (Lu, Dong \& Wang, 2007)] specialize their business models on service, product-wise innovation, elements of influence, element bonds, information and application architecture, as well as informational value exchange. Focused on this task, an integratable definition is suggested: "A business model is a description of the roles and relationships of a company, its customer, partners and suppliers, as well as the flows of goods, information and money between these parties and the main benefits for those involved, in particular, but not exclusively the customer (Bouwman \& Hulsink, 2002)." As there is no globally accepted definition of what makes a business model a business model, the theoretical foundations of most business model definitions are quite delicate and carefully worded. Furthermore, definitions for business models possess a significant variety due to the fact that they are driven by a number of different points of view. 
Table 1: Business model elements

\begin{tabular}{|c|c|}
\hline Authors & Elements \\
\hline Afuah and Tucci (2001) & $\begin{array}{l}\text { Revenue, connected activities, customer value, scope, price, sustainability, } \\
\text { implementation, capabilities }\end{array}$ \\
\hline Alt and Zimmerman(2001) & Revenue, mission, processes, structure, technology, legalities \\
\hline Amit and Zott (2001) & Transaction governance, transaction content, transaction structure \\
\hline Applegate (2001) & Concept, value, capabilities \\
\hline Betz (2002) & Capital, resources, profits, sales \\
\hline Chesbrough & Internal value chain structure, target markets, value proposition, competitive \\
\hline Rosenbaum(2000) & strategy, value network, \\
\hline Donath (1999) & Capabilities, customer understanding, market tactics, corporate governance \\
\hline $\begin{array}{l}\text { Dubosson-Torbay } \\
\text { al.(2002) }\end{array}$ & Products, partners network, customer relationship, financial aspects \\
\hline Gartner (2003) & Core technology investment, market offering, competencies, bottom line \\
\hline Gordijn et al (2001) & $\begin{array}{l}\text { Market segments, stakeholder network, value offering, value activity, value } \\
\text { interface, value ports, value exchange, actors }\end{array}$ \\
\hline Hamel (2000) & Strategic resources, value network, core strategy, customer interface \\
\hline Horowitz(1996) & Product, organizational characteristic, price, distribution, technology \\
\hline Laudon and Traver (2007) & Revenue model, value proposition, partners \\
\hline Linder and Cantrell(2001) & $\begin{array}{l}\text { Revenue model, pricing model, Internet-enabled commerce, channel model, } \\
\text { relationship, commerce process model, convenience model, intermediary } \\
\text { model, trust model, organizational form, value proposition, innovation model, } \\
\text { commodity-plus model }\end{array}$ \\
\hline Magretta(2002) & Revenue, product, value creation, capital,...... \\
\hline Mahadevan (2000) & Revenue, value creating process, product offering, organization \\
\hline Markides (1999) & $\begin{array}{l}\text { Product innovation, infrastructure management, customer relationship, } \\
\text { financial aspects }\end{array}$ \\
\hline $\begin{array}{l}\text { Osterwalder and Pigneur } \\
\text { (2005) }\end{array}$ & $\begin{array}{l}\text { Value proposition, target customer, distribution channel, relationship, value } \\
\text { configuration, core competency, partner network, customer structure, } \\
\text { revenue model }\end{array}$ \\
\hline Petrovic, Kittl et al.(2001) & $\begin{array}{l}\text { Revenue model, resource model, production model, customer relation model, } \\
\text { value model, market model, capital model }\end{array}$ \\
\hline Rappa $(2001 ; 2002)$ & $\begin{array}{l}\text { Revenue model, value proposition, brokerage, information, merchant, } \\
\text { manufacturer, community, affiliate }\end{array}$ \\
\hline $\begin{array}{l}\text { Rayport and Jaworski } \\
(2001,2004)\end{array}$ & $\begin{array}{l}\text { Revenue resources, resource system, market space offering, financial model, } \\
\text { value cluster }\end{array}$ \\
\hline Stahler (2002) & Value proposition, products/service, architecture, revenue model \\
\hline $\begin{array}{l}\text { Tapscott, Ticoll et al. } \\
(2000)\end{array}$ & Value chain, alliance, product/service, distribution \\
\hline Timmers (1998) & $\begin{array}{l}\text { Revenue sources, business actors and roles, products/services/information } \\
\text { flow architecture, marketing strategy, actors benefits }\end{array}$ \\
\hline $\begin{array}{l}\text { Viscio } \\
\text { Pasternak(1996) }\end{array}$ & Services, business units, global core, governance, linkage \\
\hline Weill and Vitale (2001) & $\begin{array}{l}\text { Revenue sources, products/service, value net, strategic objectives, channels, } \\
\text { value proposition, , success factors, IT infrastructure, core competencies, } \\
\text { intermediary, customer segments }\end{array}$ \\
\hline
\end{tabular}

\section{Approaches about business models}

Our interest in business models is relatively recent, with a majority of our research being from the past decade, from an era created through the 'new economy'. According to Chesbrough \& Rosenbloom (2002), the origins of the concept of a business model has roots which trek back to 'Strategy and Structure', an influential book written by Chandler in 1962. Strategy, as Chandler says, "can be defined as the determination of the basic long-term goals and objectives of an enterprise, and the adoption of courses of action and the allocation of resources necessary for carrying out these goals" (Chandler 1962). Further conceptualizations move 
through Ansoff's (1965) thoughts about corporate strategy, then through Andrews' (1980) corporate and business strategy definitions, which can be thought of as the predecessor of and founding bricks of a business model definition, according to Chesbrough \& Rosenbloom (2002). Electronic commerce has generated the largest amount of research (Mahadevan, 2000). Also earlier works aimed for web-based firms to capture revenue streams. Ensuing work categorized types of models as offering products, value creations and firm architecture, among other elements. A business model is defined in a distinct and comprehensive manner. Economic model, customer interface, partner network, internal infrastructure and target markets are the most commonly mentioned elements of different business model definitions which are an enterprise's value offering reported by Morris et al (2005). The belief of most definitions of business models, direct or indirect, is a business model should explain 'business relations' behind the creation of value of a specific service or product. Giovanni Camponovo \& Yves Pigneur talked about the function of key elements with ontology for defining and analyzing their business model in a mobile business environment (Camponovo \& Pigneur, 2003). Afuah and Tucci evaluate business models as a componential system (value, revenue sources, price, related activities, implementation, capabilities and sustainability) made up of relationships, and interrelated technology (Afuah \& Tucci, 2001). In light of these basics, progress in this field has been turned sluggish by the absence of an agreement over the elements of the model. Table 1 presents an analysis of the existing points of view in regards to the separate elements of a model. These perspectives are distinct for both their similarities and differences to each other. The quantity of elements mentions differs from three to thirteen.

This table is an update of Michael Morris et al (2005), 38 totaling items are cited, 23 of those receive multiple mentions in the next table, Table 2. Frequently cited are a firm's revenue model (13), product and service (12), proposition of value (11), customer/customer relationships (10), value chain/net (9), partner network (7), organization/internal infrastructure (7), target markets (7),core competencies(6), and capital(6). A few elements overlap with each other, for example customer relationships and the firm's partner network or the firm's revenue model, products and value proposition. This inability to create consensus has slowed progress in a number of issues in related fields. Few insights are available which relate to the situations that make specific models suitable, methods in which models react between organizational variables, generic types of models, and model evolution dynamics among others. Efforts at decomposing models acknowledge the existence of interdependencies among various other components but clarify very little about the nature of these relationships. Progress which has been limited has also been made in creating methodologies for evaluating the quality of models.

Business model on technology based learning: By analyzing the literature of a business model intended for learning, we pursue an overall description of a business model domain. First the origin of 'business model' as a term is explored, followed by a short but detailed definition detailing the elements of a business model. The most up to date research frameworks are then analyzed, portraying a ripening domain of research. Finally, Mlearning specific models are conferred. From the next paragraph we assess research in the E-learning field which are done aimed at E-learning business models. Erik Wallin and his colleague created an e-learning value chain (Wallin, Henningsson \& Möller, 2004) and stated an e-learning life cycle founded on the four value times of Jean Baudrillard in order to explain the value chain within a functioning e-learning business model. In a later time, Jan Mendling demonstrated that a significant potential exists making a revenue off of elearning, (Mendling, Neumann, Pinterits \& Simon, 2005), however a single revenue model is barely enough to cover the cost of e-learning. Hoppe and Breitner classified six groups which contain (i) Content providers, (ii) Application providers, (iii) Hardware providers, (iv) Service providers (e.g. tutorial assistance), (v) Hosting services, and (vi) Full service providers (Hoppe \& Breitner, 2003). As we have covered, most research done on the topic of e-learning business models tends to reference e-learning value chain to demonstrate elearning models. Unfortunately there is an absence of research for mobile learning business models. Only Dipl Ok says in a sentence that his suggested business model for e-learning can work for m-learning (Ök.D, Hoppe, \& Breitner, 2004). It is clear that within the information communication technology based innovation domain, such as m-learning, interdependencies within the acting elements both at the supply and demand side, as well as in interactions between the two, lead to major mass and network matters. In many cases, newer Internet and mobile innovations can purely be introduced by collaboration with the infrastructure, middleware and service providers. These collaboration types which are internal and external to the firm, are not structured and institutionalized although they more many times more closely associated to business actors and their niches and position (Bouwman, MacInnes \& Reuver, 2006). 
Table2: Frequency of business model elements

\begin{tabular}{llllll}
\hline Row & Elements & Frequency & Row & Elements & Frequency \\
\hline 1 & Actors & 3 & 20 & Legalities & 1 \\
2 & Affiliate & 1 & 21 & Manufacturer & 1 \\
3 & Bottom line & 1 & 22 & Market model & 7 \\
4 & Brokerage & 5 & 23 & Merchant & 2 \\
5 & Capabilities & 3 & 24 & Organization & 7 \\
6 & Capital & 6 & 25 & Partner network & 7 \\
7 & Channel & 5 & 26 & Price & 3 \\
8 & Commodity model & 2 & 27 & Processes & 4 \\
9 & Concept & 1 & 28 & Product/service & 12 \\
& Connected & & & & \\
10 & activities & 1 & 29 & Profit model & 2 \\
& Convenience & & & & \\
11 & model & 1 & 30 & Resource model & 4 \\
12 & Core competencies & 6 & 31 & Revenue model & 13 \\
& & & & Strategy & \\
13 & Cost structure & 1 & 32 & objective & 2 \\
14 & Customer & 10 & 33 & Success factors & 1 \\
15 & Global core & 1 & 34 & Sustainability & 1 \\
16 & Governance & 4 & 35 & Technology & 4 \\
17 & Implementation & 1 & 36 & Trust model & 1 \\
18 & Information, & 1 & 37 & Value chain/net & 9 \\
& & & Value & \\
19 & Innovation model & 1 & 38 & proposition & 11 \\
\hline
\end{tabular}

\section{Theoretical framework of business models}

Matters which relate to theory represent another grey area which is not receiving enough attention. An exception which remains notable can be spotted in Amit and Zott (2001), who approach the creation of business models as a unifying series of analysis that pins down value creation which comes from multiple sources. Amir and Zott argue in favor of a theoretical perspective, they conclude that no sole theory can explain in full that potential value creation ability of a venture. A theoretical perspective represent business model as a term 'prior ideology' covers the aspects of an organization's vision and value proposition, objectives, and strategy, while 'operating effectiveness' is viewed as an outcome of the organizational strategy and the elements: scale of operations, technology, structure, and human resources (Child, 1972). Child does implicitly refer to his schematization of "the role of strategic choice in a theory of organization" as a business model representation. The construct of the business model builds upon foundation ideas in business strategy and its associated theoretical traditions. In the most direct interaction, it builds upon the concept of value chain (Porter, 1985) and the extensive traditions of value systems and strategic positioning (Porter, 1996). Due to the fact that business models encompass competitive advantage, it also builds on resource-based theory (Barney et al., 2001). In the approach which examines the firm's position within the bigger network of value creation, the model associates to the theory strategic network (Jarillo, 1995) and strategies for cooperation (Dyer and Singh, 1998). Furthermore, the model brings into involvement a series of choices (e.g., vertical integration, competitive strategy) about the boundaries of firms (Barney, 2001) and associates to economics of transaction costs (Williamson, 1981). Generally different viewpoints towards a model include the undertaken offerings and activities a firm takes to create them. From here, the management should evaluate the firm's value proposition, choose the activities it will undertake within the firm, and determine how the firm fits into the value creation network. Based on Schumpeter's (1936) theory of economic development, value is generated through unique exploitations of resources that allow innovations while transaction cost economics defines transaction efficiency and boundary decisions as a source of value. Positioning within the bigger network of value can be a factor of critical importance in value creation. For its positioning, the firm requires to establish a proper relationship with suppliers, partners and customers. Models implicitly or explicitly address the internal competencies that exist within the under-foundations of a 
firm's competitive advantage. This fits in with resource-based theory, in which the firm is evaluated as a bundle of resources and capabilities (Barney et al., 2001). Advantage in competition can emerge through execution of particular activities within the firm's internal value chain in a superior manner, superior coordination among those activities or superior interface management between the firm and others in the value network. Also, in spots where the model possesses proprietary innovative elements, resource advantage theory remains relevant (Hunt, 2000).

The venture's economics are prominently featured in its business model research. An effective model encompasses unique combinations which create an opportunity for higher value creation, in return producing higher returns for the firm, which fits with the Schumpeterian theory (Schumpeter, 1936). At the same time, the growth and profit ambition of entrepreneurs change with a considerable amount through the board. Ambitions reflect the relationship that the firm creates to the career, life and influence objectives that the entrepreneur sets for the enterprise. Business models will differ between ventures which are aimed at moderate versus ambitious ambitions, this only stands to add to the diversity. Different theoretical traditions create implications for entrepreneurial intentions in observation at the nature and extent of the venture. Selfefficacy theory is a case in point, it has emphasis on the role of the cognitive capabilities and skill assessments of an entrepreneur in determining results. In contrast, the theory of effectuation suggests that conjectures are created by entrepreneurs which forecast the future in order to determine what can be done and helping the emergence of goals over time (Wiltbank and Sarasvathy, 2002). Moreover another theoretical perspective which represents Sweet (2001) recognizes the complicated bonds between creation of value, strategy and business models, and argues that the fundamental strategic value configuration logics management, such as supplier relationships, technological access, closeness to the needs of the users and etc are far more influential than taking into use newer and revolutionary business models. Within these bonds and interrelations created value can be discovered. Creation of value can be related to "solving a problem, improving performance, or reducing risk and cost" (Sandberg 2002) which could perhaps require specific configurations of value (cf. Sweet 2001) within these, including supplier bonding, technological access, closeness to the needs of users and etc. An added theoretical point of view approaches the business model as interconnected partitions of a system that creates the firm's architectural backbone. With systems theory, the firm is seen as an open system with differentiating levels of combinatorial composite of subsystems, environment and information exchange bounded (Petrovic et al., 2001).

Model development: Building on the concepts and theoretical roots it is possible to develop a comprehensive, logical, operational yet simple business model framework for the industry of mobile learning. The main challenge is to create a framework that is useable within the entire mobile learning industry in general, which at the same time serves the unique needs of each individual mobile learning provider and institution. Accordingly a framework is proposed which consists of different providers and actors. Further, with each actor and provider, five fundamental decision areas related to the business components and different managerial functions of model are present.

Basic business elements: Five of the most common elements have been dug out amongst the various perspectives found in the literature and cases which include those summarized within table 2.

Consequently, the consideration of the following five questions which underlie a business model and its elements is important.

- What is value proposition of provider in m-learning industry?

- For whom provider creates value in m-learning service?

- What are core activities in mobile learning?

- Who are business partners in m-learning industry?

- What are our revenue sources or revenue model for providers?

Moreover, each of these questions has a foundation in the theoretical work earlier discussed. The most consistently bolded elements are related to the value proposition, the customer/customer relationship, product/service, core competencies, business partners and revenue sources. Finally, a reliable framework should apply to a mobile learning business. Let us examine each in more detail.

What is value proposition of provider in m-learning industry? The first question is about the value offerings of the firm. The here addressed decision relate to the nature of the product/service mix, the firm's 
role in production or service delivery, and how the offering is made available to customers. The business cannot exist without a defined value proposition, and the creation of value is a justification provided for the entity of the business. Its inclusion in the model is supported by the work of Afuah and Tucci (2001), Chesbrough and Rosenbaum (2002), and Rayport and Jaworski (2001), amongst others.

For whom provider creates value in m-learning service? This question focuses on the nature and scope of the mark within which the firm participates. Who is the intended buyer of the firm and where inside the chain of value will it operates? Customer types, their geographic dispersion, and their standards of interaction have a major impact on how the configuration of the firm, its resource requirements, and its sales are laid out. Not being successful to adequately define the market is a major element associated with a failure to venture. Costumer role support in regards to defining an organization's business model can be found in Gordijn et al., 2001, Markides, 1999, and Timmers, 1998.

What are core competence/activities in mobile learning ? The term 'core competency' is an expression used to describe an internal capability or set of skills which are unique to the firm itself or done at a higher level of quality compared to others (Hamel, 2001). Development and continuous development of this unique ability found the function of the firm in the external value chain and create a manageable focus for the internal value chain. These competencies are centered within the core of the business model (Applegate, 2001; Viscio and Pasternack, 1996). A firm may attempt to create a platform and build their advantages around one or multiple competencies, with general advantage sources diagnosed by different observers (Siggelkow, 2002).

Who are business partners in m-learning industry? The existence of exclusively managed vital assets and natural monopolies requires organizations to create and partner within an operations web. As a matter of fact, until now, no organization has managed to thrive in providing an end-to-end solution between the content owner and the end-user without external partnership. Partnership management is therefore very probably the future core activity of a majority of mobile business enterprises. The element of infrastructure also pushes the firm to work with both internal activities and a network of partnerships with outside parties.

What are our revenue sources or revenue model for providers? An element which cores the firm's business model is the economic model of the firm (Linder and Cantrell, 2001). The economic model is a consistent pathway towards financial earnings and profit for the firm. It can be explained in terms of four subcomponents: operational leverage or the extent to which the structure of costs is dominated by fixed or variable costs; the firm's emphasis on market opportunity and internal capacity in terms of higher or lower volumes; the firm's ability to meet goals in a relatively high or low margin; and the revenue model used inside the firm, including the flexibility of prices and sources of revenue.

M-learning Business players: The pursuit of opportunity is closely related to the business model as it is a boundary object. (Sanz Velasco, 2007) It bonds multiple varying elements and enhances communication. Within this business model framework, as in m-learning, we consider the 'business relation' concept of business models by position investigation, roles and interrelations of varying elements part taking in the $\mathrm{m}$ learning sector as well as influences which are sourced towards the operational environment (such as government) on a business model. From this viewpoint, a definition can be adopted to meet our needs: A business model provides a description of the roles and relations of a firm, its intended audience, suppliers and business partners, as well as the goods flow, information and capital exchange between the parties and the key benefits for involved parties, specifically but not only, the costumer. (Bouwman, 2002) For evaluating the position played by important m-learning business elements, it is recommended to provide a short and to the point business description for clarifying their business models. Based on a broad literary review and case studies, the following six basic business elements in the mobile learning field were selected: user, government, content providers, communication providers, hardware providers, and service providers. The states six elements can be utilized to describe the business relations of business models and are similar to the mechanisms as for instance utilized by Camponovo and Pigneur (2003). A graphic framework of a business model for an m-learning firm is shown in Figure 1. 
Figure 1: M-learning pentagon business model environmental framework

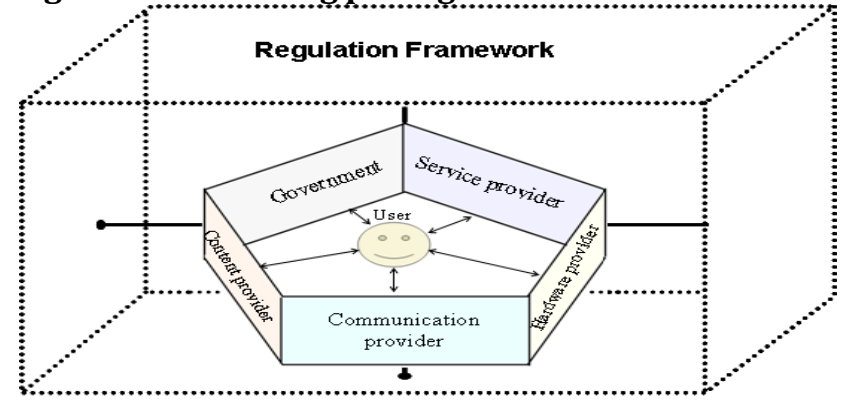

The sides in the pentagon framework represent elements in sectors of m-learning. The central circle inside the pentagon shows the targeted user audience which has been targeted by the firm. The environment of the business is surrounded by regulatory principles and standards which are directly influenced by the government and other related authorities. Figure 1 shows how the m-learning service requires support from a partnership of a multitude of business players. The literature in m-business and e-learning express the actors which are involved in communication and content provision which can be used also in m-learning (Hadzilacos \& Tryfona, 2005), as well as a few journals which explore the m-learning providers. Certain authors bond through a parallel shared set of key elements of the mobile business network, which they categorize into three categorical groups of majority: technology, network and application. However we recommend categorizing these elements according to the framework of figure 1 which illustrates in detail. In the central hub of the m-learning environment is the user, who has necessities relating to their m-learning needs. In order to provide for these necessities, we explore five vital partitions: content, regulation, communication, hardware and services, and in the general picture, these partitions are all surrounded by a framework of regulations.

User: Business models cannot be planned out while in a lack of knowledge about the needs of likely costumers of value added mobile learning (Parsons, Ryu \& Cranshaw, 2006). The service target is the user and its needs. A user will need to be served and have his needs fulfilled. He has to be treated in a special, simple and a visible approach (Peters, 2007). The user can exchange value or payments for the service if it meets a certain quality or is run in a certain way. Or users the central object of concern should always be reflected in the business model, as a result the user is the most important element and the ultimate judge for the success or failure of an m-learning service. Users can be listed as the end user (student), companies and firms, universities and educational institutes and all other parts of a value net for mobile learning services. It is helpful to approach certain elements with special needs in learning and mobility separately, for example those who travel and would have an interest to study at the same time, those who have no access to educational institutes or an educational system which is based on the web, or those who require fast and urgent knowledge, for example healthcare. Firms whose manning staff spend their time away from office and have a regular need for training, or universities and institutes which require mobile learning within their curriculum of education or as a part of value net all use m-learning. Users can frequently involve in consultation and information services, law assistance and lobbying.

Government, Regulation and Standard Authorities: Educators and professionals have long established that there is a need for standards in m-learning (Grohmann, Anja \& Martin, 2005). The M-learning training system and education will reflect strongly upon its constituting documents, regulations and standards will define the way m-learning will be used in education systems. Regulations for the industry enclose upon a general strategy and road map for mobile learning, and topics such as display resolutions, memory, storage, mobile device processing capacities, considered default specifications for both hardware and software on mobile devices and supporting devices will be covered by m-learning standards. Standards and regulations are aimed at helping teachers and developers by providing information about the nature of mobile devices and the baseline notions that inform and ease the decision making process to optimize the use of mobile devices (O'Connell \& Smith, 2007). Governments, regulatory offices, standardization groups and other involved powers are key elements in the area of regulation. This group of elements will set the discipline and foundations upon which the legal environment of the m-learning field will develop and can have substantial 
control over other players. Systems of regulation create the law structure which creates the highly competitive m-learning services from which people and the market can choose from. Governments set a general education system environment by installing an education policy, defining curriculums, legislation and degree validation so on, while standardization groups create the disciplinary environment through technical standards with an extensive variety. Regulation authorities advise and co-operate with all indirect or third parties in order to create a valid legislation that meets their varied needs properly (Camponovo \& Pigneur, 2003). These authorities are government managed and are under the influence of different lobbies (Diso, 2008). The functions of these players are the development of legislation, regularity allocation management, management of service licensing, market monitoring for the guarantee of legislation fulfillment and antitrust requirements. These factors are not usually revenue oriented, however they can create earnings through licensing fees and taxes.

Content Provider: "Content is king" has evolved into a famous expression to illustrate how important content creation has become as a segment of market providers (Ök, Hoppe \& Breitne, 2004). M-learning conditioning requires the intensive use and distribution of information and data by the providers of $\mathrm{m}$ learning content. Providers of content offer content which has been created beforehand. Content has either gone through standardization, or personalized, or individualized. Often content is obtained from publishing houses. These contents can be data and information products such as courses, books, may also include exams and quizzes and so on in text form, audio and audiovisual formats. Other actors, called content aggregators, mix and dispense varied formats of data and information targeting particular users. Content aggregators frequently generate mobile portals which become accessible from mobile phone screens, PDAs or other wireless devices. Often content providers, content aggregators and portals create an interrelationship with the goal of pushing the reach of their products further as well as reach content owners, press groups and various other businesses which are media oriented in order to get favorable access to raw information. Other useful partners are composited of network operators who agree on a beneficial allocation of revenue for a business model and payment agents. Corporations might create agreements with application providers for their platforms of content management. A content provider's revenue roots to the fees charged for subscriptions, fees for usage, syndicate contracts plus airtime revenue sharing. Their work includes the design of instructional, didactic planning, content collection, processing and arrangement of content, content publishing, distribution of content, management of distribution agreements, pre-packaged content in strategic points of the academic pathways and product promotions (Camponovo \& Pigneur, 2003).

Communication Provider: Network sourced m-learning content is crucial for mobile hardware to be able to effectively engage in the mobile learning business environment. The proper mix of mobile hardware with mobile technology is the deriving factor behind the growth and progress of this trend (Caudill, 2007). The most dominating factors in networking technology for mobile devices are mobile network operators or carriers, virtual portal operators, internet services providers, infrastructure management service providers. Mobile network operators are the most crucial and impactful element in the field of communications.

Mobile network operators: Operators of mobile networks most likely play the most crucial role in enabling m-learning. Carriers offer far reaching communication services to learners. On the side of this, they also provide a spectrum of relevant network services, as an example, geographic information, user recognition and third party billing services. Network providers are tending to network promotion, contract management, service provisioning, infrastructure operations which deal with caring for the client, sales, problem management, invoicing, service development and operating, quality management, network planning, deployment, maintenance, and systems management. Mobile network operators who offer services which require partnerships with different kinds of niche based firms such as infrastructure vendors, other network operators and ISPs. They also need the help of content provider partners, application providers, service providers, virtual operators and portals. Mobile network operators most frequently offer their services to students, application providers, virtual operators, ISPs, and other businesses. They are strategically positioned to gain from the opening of new information services which are revenue generation capable, this is due to them having established relationships with their costumers regarding invoices and billing. Other segments of their revenue come from subscription fee policy, including airtime fees and quantity-based fees. They additionally receive revenues from services given to other parties, specifically network related, and transaction fees (Camponovo \& Pigneur, 2003). 
Internet service providers: ISPs offer on hand internet network access to end users, other ISPs and operators of networks, as their main source of revenue is their user subscriptions and transfer agreement with outside networking businesses, for example the ISPs and network operators mentioned above. Internet service providers need to put their attention on network promotion, management of the goings-on of contracts, service provisioning and infrastructural operations, however these services cannot be provided by the firm alone and require a partnership with other actors. ISPs buy internet equipment from vendors specializing in network infrastructure to make up their own networks and to connect through gateways, to other networks. These companies have to create agreements about traffic, among network operators, to increase their reach to their client with extra ISPs with the goal of making it possible for their users or customers are connected to the entire internet. They will perhaps partner with content and application providers as well, in order to create a distinct character for their offerings.

Hardware and Device Providers: Probably the first piece of hardware which pops into mind while we discuss mobile hardware is the PDA. This technology presents the many features of a personal laptop computer or a desktop in a compact pocket-fit device. Mobility is a key ingredient in the success of a piece of mobile learning hardware (Caudill, 2007), and a limited number of devices present the offer of mobility and its combined features like the PDA does. However in a majority of cases, hardware is not specifically designed for mobile learning purposes. As a result hardware providers can often supply technologies with non-mlearning capable segments. Specific m-learning hardware may or may not be required due to the specific needs of certain types of data and file formats. In the hardware field, the important elements are handheld and mobile device manufacturing companies and networking equipment suppliers or vendors.

Device manufacturers: Device manufacturers compose the fundamental pieces of the m-learning value net. As a result, they often push towards the development of newer products with a wider variety (Sharples, 2007) due to the fact that applications and services in the future will need an integrative nature which makes downloading different kinds of learning materials easy, both in audiovisual and text systems. Device manufacturers offer the mobile phone device, PDA, iPod, or other sidekicks of handheld device to users, which contract their learning program with a facilitator. Possible partnerships for hardware providers are the makers of components, developers of applications and operators of various networks. As an addition it is a possibility that device manufacturers would create business partnerships with content providers, application providers and portals, aiming to extend their reach and introduce useful or novel mobile services that would smoothen the acceptance of new handsets in the market. Usually device manufacturer sell their products to device retailers and network operators' distribution channels, and their main revenues come from the selling of their devices to distributors. For sustainable business, device manufacturers need to pay close attention to marketing.

Network equipment vendors: Equipment vendors supply the hardware and software mobile network infrastructure. They supply base stations, backbone, transport technologies, air interfaces, routers and switches which address the center of technical mobile network infrastructure. They also provide network management systems, billing systems, etc. to operate and manage the network in the logical framework. They supply these products to network operators and money from these services provides equipment vendor's revenue. The main goals for vendors of hardware and equipment are R\&D, production, system development, and the provision of services related in nature to the infrastructure. Equipment vendors make tight collaboration with component vendors plus application developers as a buyer and network operators as a supplier.

Service and Application Providers: The SP (Service Provider) offers their services through software and applications. They are there to assure that the service is usable or usable at a certain quality standard. The SP's job is to facilitate the payments a user makes for a service, or for a specific quality service. M-learning services add to the flowing of m-learning content by m-learning applications. M-learning services can directly relate to learning processes. M-learning services can also have a supporting function, such as software support, consulting services, payment agent, security solution providers, integration, advertising company, ebusiness, remote access, and maintenance. The providers are not always the source of the service they provide or the produced product. They may use services by themselves to generate a new service or a valueadded version. The most important actors in the service sector are application providers and payment agents. 
Application providers: Application providers present the market with mobile learning software solutions. On many occasion they work closely with content providers (Ök, Hoppe \& Breitner, 2004); Sometimes, applications are complimentary or shareware. They provide mobile applications and platforms perhaps containing variety kinds of applications related services. For example: remote access to different range of applications that are run in a central location, with m-learning management system, hosting, implementation, integration, support and maintenance services. These applications are provided for a variety of players in the m-learning value net such as students, institutes, universities, authors, network operators, portals, businesses, and device manufacturers. Application providers work with content providers often, m-learning centers, and network operators in order to guarantee an adequate quality of services and expand access to necessary network services. In addition, they cooperate with device manufacturers to make sure of compatibility with the different current and future devices and as a sales partner. Application providers' core tasks are application development, infrastructure operation, application management, integration, support and consulting services. Their revenue comes from contracts to host, operate and maintain services, consultation related services, administrative training, content direct linking, maximizing access to third-party content, and finally, establish, manage and report digital right, rules and requirement for learning content.

Payment agents: Payment agents offer a way of payment to students, or other users, for learning services through the use of a mobile phone. Generally payment mediators are different financial organization partners such as banks, credit card companies in support of payment processing and get access to their customer's accounts (Kreyer, Pousttchi \& Turowski, 2002). Other important partners can be network operators who prefer billing and services related to collection, as well as device manufacturers for device interoperability and particular payment features, hardware providers and software developers and extra service providers. Payment agents' main activities are billing and collection, payment platform development and management, pay, banking and processing facilities and their income derives from subscription and transaction fees.

Framework applying for Nokia Mobile English Learning: Nokia is amongst the top leaders in the world in mobility, pushing the transformation and growth of the joining industries of internet and communications. Nokia is a big exporter of mobile communication industries of China. It has R\&D centers, manufacturing facilities, and offices in mainland China, Hong Kong, Taiwan and Macao. Nokia has more than 12,000 employees within the territories of China (including Nokia Siemens Networks). In 2007, Nokia announced to practice the first M-learning project, named mobiledu.cn, in China . Mobiledu is a wireless learning solution that combines hardware, content, and services for students to learn and share in a successful and resourceful manner. Nokia Director of Mobiledu.cn, Peter Zhang, said: "As a new interactive learning tool, Mobiledu.cn makes learning possible anywhere and anytime, and that is why it has been very popular in the market". The Mobiledu (行学一族) internet site is a real-time and internet-based platform for mobile learning, hosted on mobile phones, creating learning opportunities to be mobile, anywhere. Hundreds of millions of Englishstudying students in China now have the ability to use their phones in taking courses provided by mobileedu.cn to study authentic English. Nokia sales and marketing manager of Mobieldu.cn, Angela Long says, "Mobiledu.cn provides content which meets the various demands of users on learning, work, entertainment and life in general". According the framework mentioned above, we can define the components of Mobiledu as follows :

Products: Mobiledu.cn's content providers are some of the best well-known and respected brands in the field, and its Learning English content service having brought into the market, mobiledu.cn is aiming to offer the users an improved learning experience. Relying on support from major and authoritative educational organizations and publishers, Mobiledu.cn offers course content with a mix of entertainment and practicality, such as English learning courses, varying tips for examinations ( IELTS, College English Test 4 and 6 materials), lifestyle covering with up to date phrases and words, sports, fashion, bars, hairdressing, food, the English of the business world, Olympics and etc. 
Figure 2: Mobiledu.cn's products for mobile English learning

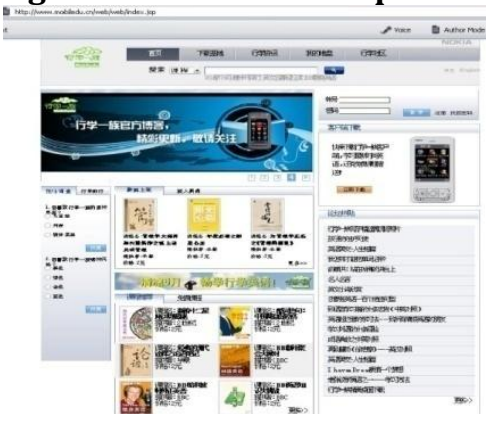

Figure 3: Mobiledu.cn partners

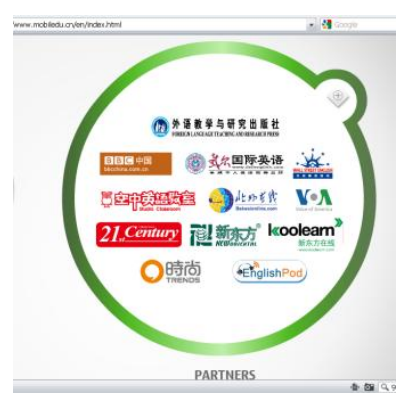

The courses can be easily downloaded through phones and handheld devices which host Nokia's Mobiledu, which is the companies learning platform on the internet.

Partners: Mobiledu.cn is willing to collaborate with China and international publishers and other parties involved in the learning field in order to offer good educational services and products to students in an easy to reach and creative way, making learning interactive for learners. In this mobile learning service, Nokia cooperates with many companies. Nokia cooperates with wide spectrum companies from several aspects, the content providers, telecommunication providers, service and software providers etc. For content providing Nokia cooperates with The BBC English, VOA, English Test Service(ETS), The DELL English, The 21th Century and the New-Oriental School etc. Nokia Company has built a good relationship with the China Mobile Communication Corporation (CMCC) and CUNC, the largest telecommunication provider in China in order to bring mobile access to its learners. If comes to the software, Nokia cooperates with the Tencent Company, which is the producer of the $\mathrm{QQ}$, message software, in China. The software could be used in many types of the cells of the Nokia and Sony Ericsson. As one of the hardware providers, Nokia cooperates with the Sony Ericsson, in that; the users can start the mobile learning not only through the Nokia cell phones, which support s 40 and s60 platform but also through the Sony Ericsson that support k-java application. As figure 4 illustrates the partnership chain of mobiledu.cn support mobile English learning delivery to learners. It has been shown Figure 4, In the process of the mobile English learning, the cooperative companies provide the English courses to Nokia. Nokia provides the platform and the mobile telephones, through which the users could download the courses to study, and through the mobile service providers, CMCC.

\section{Figure 4: mobile English learning process and partnership chain}

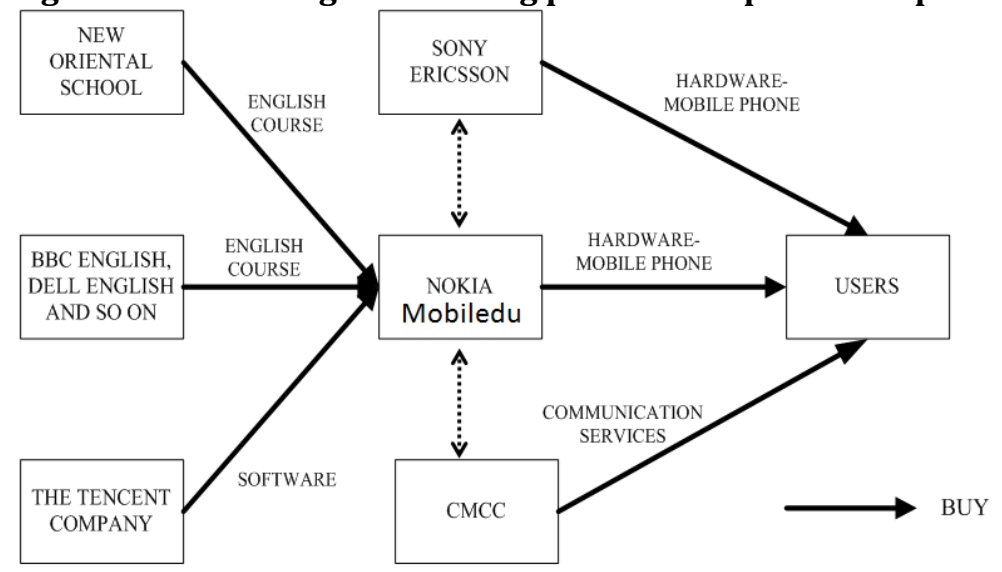

The collaboration between "Nokia and other partners will enable users to take advantage of mobile communication and Internet integration to enjoy a rich and personalized English learning experience anywhere and anytime. 
Figure 5: Mobiledu.cn business framework

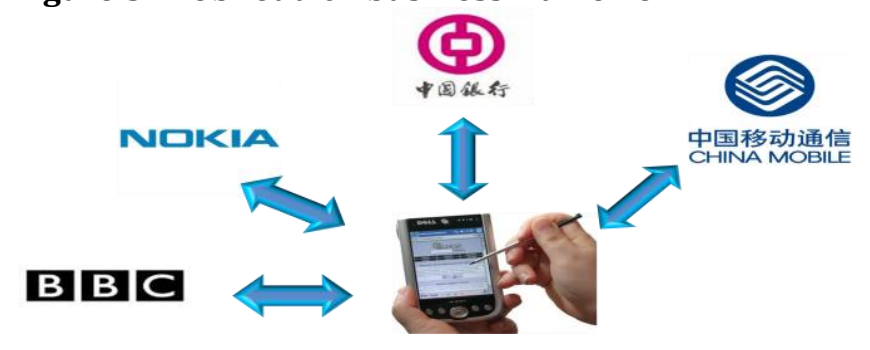

Other Nokia's partners in this project are Studio Classroom, Englishpod, koolearn, Voice of America, Wall Street English, Foreign Language and Research Press and Beijing Foreign Studies University.

Revenue: Content providers normally get the pay directly from the Nokia Company for their contents but some of them in this beginning stage of mobile English learning are not charging Nokia. The Tencent Company also gets the revenue from the Nokia Company, for the software developing. The CMCC gets the revenue, depending on the charge for the communication of the using the M-Learning from the users. As one of the mobile phone producers, the Sony Ericsson Company gets the revenue directly from the mobile phone sales to the users. At last, the Nokia Company gets the revenue, if the users, which choose to buy some courses, which attract them, use the M-learning through the mobile. As the hardware provider, the Nokia could also get the revenue from the sales of the mobile phones.

\section{Conclusion}

In this paper, we have identified and analyzed different actors of an m-learning business model, resulting in a set of six actors: user, government, content provider, communication providers, hardware providers, and service providers. All these actors are interdependent and linked to each other in reality by influence relationships whereby instances in one actor influence other instances in the same or one or more other actor. In fact, for most of the players, partnerships with a number of other actors are a significant part of their business models. Strong partnership across the value net is one of the key success factors in m-learning business. It is, however, valuable to remember that the m-learning is new and the different actors are still trailing by way of a diversity of business models to overcome in able to achieve a sustainable and profitable place in this market.

\section{References}

Afuah, A. \& Tucci, C. (2001). Internet Business Models and Strategies, Irwin, McGraw-Hill.

Alt, R. \& Zimmermann, H. D. (2001). Preface: Introduction to Special Section - Business Models. Electronic Markets, 11(1), 1-7.

Amit, R. \& Zott, C. (2001). Value creation in e-business. Strateg Manage J., 22(2), 493- 520.

Andrews, K. R. (1980). The Concept of Corporate Strategy, Richard D. Irwin, Homewood, IL.

Ansoff, I. (1965). Corporate strategy, McGraw Hill, New York

Applegate, L. M. (2001). Emerging e-business models. Harvard Bus Rev., 79(1), 79-87.

Barney, J., Wright, M. \& Ketchen, D. (2001). The resource-based view of the firm: ten years after. Journal of Management, 2, 625-641.

Betz, F. (2002). Strategic business models. Eng Manag J., 14(1), 21 - 7.

Bouwman, H., MacInnes, I. \& Reuver, M. (2006). Dynamic Business Model Framework: A Comparative Case Study Analysis. T. Lu, X. Liang \& X. Yan (Eds). 16 $6^{\text {th }}$ Conference of the International Telecommunications Society: Opportunities \& Challenges for Telecommunications, June 12-16, 2006 Beijing. pp.15

Bouwman, H., Haaker, T. \& De Vos, H. (2008). Mobile service innovation and business models. Heidelberg: Springer. ISBN 978-3-540-79237-6

Bouwman, H. \& Hulsink, W. (2002) A dynamic model of Cyber-entrepreneurship and cluster formation: applications in the United States and in the Low Countries. Telematics and Informatics, 19(4), 291313 (2002). 
Camponovo, G. \& Pigneur, Y. (2003) Analyzing the m-business landscape. Annals of Telecommunications, 58(12), January-February 2003.

Camponovo, G. \& Pigneur, Y. (2003). Business model analysis applied to mobile business, In 5th International Conference on Enterprise Information Systems (ICEIS), Angers, April 2003.

Caudill, J. G. (2007). The Growth of m-Learning and the Growth of Mobile Computing: Parallel developments. International Review of Research in Open and Distance Learning, 8(2). ISSN: 1492-3831.

Chandler, A. D. Jr. (1962). Strategy and Structure: Chapters in the History of the American Industrial Enterprise. Cambridge, MA: MIT Press.

Chesbrough, H. \& Rosenbloom, R. (2000). The Role of the Business Model in Capturing Value from Innovation: Evidence from Xerox Corporation's Technology Spinoff Companies, Working Paper, Harvard Business School, Boston, MA.

Chesbrough, H. \& Rosenbloom, R. S. (2002). The role of the business model in capturing value from innovation: evidence from Xerox Corporation's technology spin-off companies. Industrial and Corporate Change, 11(3), 529-555. http://dx.doi.org/10.1093/icc/11.3.529

Child, J. (1972). Organization Structure and Strategies of Control: A Replication of the Aston Studies. Administrative Science Quarterly, 17, 163-77.

Diso, L. I. (2008). Mobile Service Providers and M-learning in Nigeria: Mobility in a Contracting Space. iJIM, 2(1).

Donath, R. (1999). Taming e-business models. ISBM business marketing web consortium, 3(1). State College (PA): Institute for the Study of Business Markets, $1-24$.

Dubosson-Torbay, M., Osterwalder, A. \& Pigneur, Y. (2002). eBusiness model Design, Classification and Measurements. Thunderbird International Business Review, 44(1), 5-23. http://dx.doi.org/10.1002/tie.1036

Dyer, J. \& Singh, H. (1998). The relational view: cooperative strategy and sources of interorganizational competitive advantage. Academy of Management Review, 24(3), 660-679.

Grohmann, G., Anja, H. \& Martin, G. (2005). ARIS MOBILE: Helping to Define the Future of Mobile Learning, International Conference on Mobile Business (ICMB'05) (pp. 213-219) Germany: IEEE Computer Society.

Gartner. (2003). Available at: http://www3.gartner.com.

Gordijn, J. \& Akkermans, H. (2001). Designing and Evaluating e-Business models. IEEE Intelligent Systems, July-August, 11-18. http://dx.doi.org/10.1109/5254.941353

Haaker, T., Bouwman, H. \& Faber, E. (2004). Customer and network value of mobile services: Balancing requirements and strategic interests. In, ICIS, Washington, DC.

Hadzilacos, T. \& Tryfona, N. (2005). Constructive m-Learning Environments, Proceedings of the Fifth IEEE International Conference on Advanced Learning Technologies, Kaohsiung, Taiwan,(ICALT'05), July 5 $-8,2005,0-7695-2338-2 / 05$.

Hamel, G. (2000). Leading the revolution. Boston: Harvard Business School Press.

Hamel, G. (2001). Leading the revolution. Boston (MA): Harvard Business School Press.

Hoppe, G. \& Breitner, M. H. (2003). Business model for e-learning, Multikonferenz Wirtschaftsinformatik. Essen, Germany, Oct 2003, ISSN0949-9962

Horowitz, A. S. (1996). The real value of VARS: resellers lead a movement to a new service and support. Mark Comput, 16(4), 31- 6.

Hunt, S. D. (2000). A general theory of competition. Thousand Oaks (CA): Sage Publications.

Jarillo, J. C. (1995). Strategic networks, Butterworth-Heinemann, Oxford.

Kreyer, N., Pousttchi, K. \& Turowski, K. (2002). Standardized Payment Procedures as Key Enabling Factor for Mobile Commerce, Proceedings of the EC-Web, E-Commerce and Web Technologies, Aix-en-Provence, France, 2002, pp. 400- 409

Laudon, K. \& Traver, C. (2007). E-commerce: business, technology, society. 3rd ed. Pearson education.

Linder, J. C. \& Cantrell, S. (2001). Changing Business Models: Surveying the Landscape, Institute of Strategic Change, Chicago, USA, Accenture.

Lu, Y., Dong, Y. \& Wang, B. (2007). The Mobile Business Value Chain in China, Sixth International Conference on the Management of Mobile Business (ICMB 2007) 0-7695-2803-1/07, 2007 IEEE.

Magretta, J. (2002). Why Business Models Matter, Harvard Business Review, May 2002, pp. 86-92.

Mahadevan, B. (2000). Business models for Internet-based e-Commerce: An anatomy. California Management Review, 42(4), 55-69. http://dx.doi.org/10.2307/41166053. 
Markides, C. (1999). A dynamic view of strategy. Sloan Manage Rev., 40(3), 55- 63.

Mayo, M. C. \& Brown, G. S. (1999). Building a competitive business model. Ivey Bus J., 63(3).

Mendling, J., Neumann, G., Pinterits, A. \& Simon, B. (2005). Revenue Models for E-Learning at Universities, In: O.K. Ferstl, E.J. Sinz, S. Eckert, T. Isselhorst, eds.: Wirtschaftsinformatik 2005 - e-Economy, eGovernment, e-Society. Proceedings of the $7^{\text {th }}$ International GI-Conference Wirtschaftsinformatik (WI 2005), Bamberg, Germany, February 2005, pages 827-846

Issack, M. S., Hosany, M. \& Gianeshwar, R. (2006). A M-E (Mobile-E-learning) Adaptive Architecture to Support Flexible Learning. Malaysian Online Journal of Instructional Technology (MOJIT), 3(1), 19-28, ISSN 1823:1144,

Morris, M., Schindehutte, M. \& Allen, J. (2005). The entrepreneur's business model: toward a unified perspective. Journal of Business Research, 58, 726-735.

O'Connell, M. \& Smith, J. (2007). A guide to working with m-learning standards A manual for teachers, trainers and developers, Version 1.0, (C) Commonwealth of Australia 2007

Ök, D., Hoppe, G. \& Breitner, M. H. (2004). Business model for e-learning, conference proceeding in E-Learning: Models, Instruments, Experiences of the Multikonferenz Wirtschaftsinformatik 2004 (www.mkwi04.de), Essen, Germany, 2004

Osterwalder, A., Pigneur, Y. \& Tucci, C. L. (2005). Clarifying Business Models: Origins, Present, and Future of the Concept. Communications of the Association for Information Systems, 16(1). Available at: http://aisel.aisnet.org/cais/vol16/iss1/1

Parsons, D., Ryu, H. \& Cranshaw, M. (2006). A Study of Design Requirements for Mobile Learning Environments, icalt, 96-100, Sixth IEEE International Conference on Advanced Learning Technologies (ICALT'06).

Peters, K. (2007). M-Learning: Positioning educators for a mobile, connected future. International Review of Research in Open and Distance Learning, 8(2).

Petrovic, O., Kittl, C. \& Teksten, R. D. (2001). Developing business models for e-business, Proceedings of the International Conference on Electronic Commerce, Vienna, $31^{\text {st }}$ October- $4{ }^{\text {th }}$ November 2001.

Pigneur, Y. (2002). A framework for defining e-business models. Working paper, Ecole des HEC, University of Lausanne.

Porter, M. E. (1985). Competitive advantage: Creating and sustaining superior performance. New York: Free Press.

Porter, M. E. (1996). November-December). What is strategy? Harvard Business Review, 74(6), 61-78.

Pousttchi, K., Schießler, M. \& Wiedemann, D. G. (2007). Analyzing the Elements of the Business Model for Mobile Payment Service Provision, Proceedings of the $6^{\text {th }}$ International Conference on Mobile Business (ICMB 2007). IEEE Computer Society Press. Toronto, Ontario, Canada.

Rappa, M. (2001). Managing the digital enterprise - Business Models on the Web, http://ecommerce.ncsu.edu/business_models.html

Rappa, M. (2002). Managing the digital enterprise - Business models on the Web. North Carolina State University.

Rayport, J. F. \& Jaworski, B. J. (2001). E-commerce. NewYork: McGraw-Hill/Irwin, 2001.

Rayport, J. F. \& Jaworski, B. J. (2004). Introduction to E-Commerce (2nd Ed.). Pennsylvania State University: McGraw-Hill Irwin MarketspaceU.

Sandberg, K. D. (2002). Is it time to trade in your business model? Harvard Management Update, 1, 3-5.

Sanz Velasco, S. A. (2007). Technology and business model learning leading to growth: start-up ventures in mobile internet. Int. J. Techno entrepreneurship, 1(1).

Schumpeter, J. (1936). Review: The General Theory of Employment, Interest and Money by John Maynard Keynes. Journal of the American Statistical Association, 31(196), 791-795.

Sharples, M. (2007). Big Issues in Mobile Learning, Report of a workshop by the Kaleidoscope Network of Excellence, Mobile Learning Initiative, University of Nottingham.

Siggelkow, N. (2002). Evolution towards fit. Adm Sci Q., 47(1), 125- 59.

Slywotzky, A. J. (1996). Value migration. Boston (MA): Harvard Business Review Press.

Smith, A. (1981). An Inquiry into the Nature and Causes of the Wealth of Nations. Indianapolis: Liberty Classics.

Staehler, P. (2001). Geschaeftsmodelle in der digitalen Oekonomie: Merkmale, Strategien und Auswirkungen Lohmar. 
Staehler, P. (2002). Business Model Innovation, http://www.business-model-innovation.com/definitionen/ geschaeftsmodellinnovation.html.

Stewart, D. W. \& Zhao, Q. (2000). Internet marketing, business models, and public policy. Journal of Public Policy, 19, 287- 96.

Sweet, L. (2001). Strategic value configuration logics and the 'new' economy: a service economy revolution? International Journal of Service Industry Management, 12(1), 70-83.

Tapscott, D., Ticoll, D. \& Lowy, A. (2000). Digital Capital-Harnessing the Power of Business Webs", Nicolas Brealy Publishing, London.

Timmers, P. (1998). Business models for E-commerce. Electronic Markets, 8, 2, 3-7.

Varshney, U. \& Vetter, R. (2002). Mobile commerce: framework, applications and networking support. Mobile Networks and Applications, 7(3), 185-198

Viscio, A. J. \& Pasternack, A. (1996). Toward a new business model. Retrieved from: http://www.strategybusiness.com/press/16635507/14974 (dernier access November 2009).

Wallin, E., Henningsson, S. \& Möller, M. (2004). The higher value chain of eLearning, paper for E-Learning Workshop Hannover, September.

Weill, P. \& Vitale, M. (2002). What IT infrastructure capabilities are needed to implement e-business models? MIS Quarterly Executive, 1, 17-34.

Williamson, O. E. (1981). The economics of organization: the transaction cost approach. American Journal of Sociology, 87(4), 548-577.

Wiltbank, R. \& Sarasvathy, S. (2002). Patterns of business model change as measures of causation and effectuation. In: Reynolds P, editor. Research in frontiers of entrepreneurship research. Babson Park (MA): Babson College Press, 2002. p. 328. 